\title{
PEMILIHAN ALTERNATIF PENGHEMATAN ENERGI PADA PROSES PRODUKSI BATIK CAP DENGAN MENGGUNAKAN METODE MCDM-PROMETHEE
}

\author{
Much. Djunaidi, Endah Setyaningsih \\ Prodi Teknik Industri, Universitas Muhammadiyah Surakarta \\ Jalan Ahmad Yani, Pabelan, Kartasura, Sukoharjo 57162 \\ much.djunaidi@ums.ac.id, endahsetyaningsih2@gmail.com
}

\begin{abstract}
Abstrak
Batik merupakan budaya tak-benda warisan manusia bagi bangsa Indonesia yang telah diakui oleh dunia. Industri batik cap masih banyak dikelola oleh masyarakat secara tradisional. Penggunaan energi dalam proses pembuatan batik cap perlu ditingkatkan efisiensinya. Artikel ini membahas tingkat efisiensi energi pada pembuatan batik cap, pada UMKM yang ada di Kampung Batik Laweyan, disertai dengan usulan alternatif untuk peningkatan efisiensi energinya. Perhitungan efisiensi energi dilakukan pada tiap proses yang dilakukan dalam pembuatan batik cap. Usulan perbaikan dilakukan pada proses yang kurang efisien, dengan menggunakan metode multi-criteria decision making (MCDM) - Preference Rangking Organization Method for Enrichment Evaluation (PROMETHEE). Dari analisis diperoleh bahwa tiap proses memerlukan jenis energi yang berbeda. Usulan perbaikan yang dihasilkan juga berbeda-beda untuk masing-masing jenis energi.
\end{abstract}

Kata kunci: batik cap, penghematan energi, pengambilankeputusan, PROMETHEE

\section{PENDAHULUAN}

Batik merupakan keseluruhan teknik, teknologi, dan pengembangan motif yang menjadi budayadi Indonesia.Industribatik merupakan industri yang cukup berkembang di berbagai daerah di Indonesia, dengan kekhasan yang dimiliki oleh masing-masing daerah.Batik Indonesia yang sudah diakui oleh UNESCO (United Nations Educational, Scientific and Cultural Organization)sebagai budaya tak-benda warisan manusia (the intangible cultural heritage of humanity) pada tahun 2009 [1].

UNESCO mengakui bahwa batik menjadi simbol budaya rakyat Indonesia, mulai dari lahir sampai meninggal.Bayi digendong dengan batik yang memiliki corak pembawa keberuntungan, dan yang meninggal juga ditutup dengan kain batik. Pakaian sehari-hari dipakai secara rutin dalam kegiatan bisnis dan akademis memiliki corak tertentu.Berbagai corak yang laindipakai dalam berbagai upacara adat, seperti pernikahan, kehamilan, dan berbagai penampilan kesenian. Kain batik bahkan memainkan peran utama dalam ritual tertentu [2].

Batik terkait dengan identitas budaya rakyat Indonesia.Beragam corak batik yang ada di Indonesia menandakan adanya berbagai pengaruh dari luar negeri. Ada pengaruh dari kaligrafi Arab, bunga cherry dari Jepang,burung phoenix dari China, sampai burung merak dari India atau Persia, menandakan keterbukaan bangsa Indonesia. Tradisi membuat batik diturunkan dari generasi ke generasi, dan melalui berbagai arti simbolik dari warna dan corak mengekspresikan kreatifitas dan spiritual rakyat Indonesia[3].

Kota Solo merupakan salah satu kota penghasil batik yang terkenal di Jawa Tengah. Salah satu sentra UKM penghasil batik di kota Solo adalah Kampung Batik Laweyan.Batik mempunyai berbagai jenis, seperti batik cap, batik tulis, batik printing, dan sebagainya.Seiring dengan perkembangan zaman batik dituntut dapat bersaing dengan produk lain. Produk batik harus mempunyai keunggulan dibandingkan dengan produk pesaing.Saat ini Forum Pengembangan Kampoeng Batik Laweyan (FPKBL) yang merupakan organisasi yang memiliki perhatian pada pengembangan usaha batik, berencana menjadikan batik Laweyan sebagai pelopor green-eco batik [4].

Salah satu hal yang perlu diperhatikan dalam penerapan green-eco batik adalah penggunaan energi dalam proses produksi batik. Tingkat penggunaan energi dalam proses produksi akan memberikan dampak yang signifikan terhadap lingkungan [5]. Oleh karena 
itu, pengelolaan energi baik dari sisi supply maupun dari sisi demand perlu diperhatikan dengan seksama. Dari sisi demand, perusahaan perlu melakukan konservasi energi dalam proses produksinya. Hal ini dikarenakan penggunaan energi yang belum efisien[6].

Upaya untuk konservasi energi antara lain dapat dilakukan dengan penghematan konsumsi energi [7]. Hal ini juga selaras dengan target pemerintah Indonesia untuk meningkatkan mitigasi gas rumah kaca dan mewujudkan sustainable development goal (SDG), serta mewujudkan ketahanan energi nasional dengan mengembangkan konsep industri hijau (green industry). Industri hijau adalah industri yang dalam proses produksinya mengutamakan upaya efisiensi dan efektivitas penggunaan sumber daya secara berkelanjutan [8]. Peningkatan produktivitas perusahaan dapat dicapai dengan peningkatan efisiensi dan efektivitas penggunaan sumber daya [9].

Usaha yang perlu ditempuh oleh perusahaan untuk meningkatkan efisiensi dan efektivitas dalam penggunaan sumber daya energi, perlu mempertimbangkan berbagai hal yang terkait dengan permasalahan tersebut. Pendekatan yang dilakukan dengan mengakomodasi berbagai kriteria dalam mengambil keputusan sering disebut dengan multicriteria decison making (MCDM) [10]. Beberapa perangkat telah dikembangkan untuk melakukan analisis dengan kriteria majemuk ini. Salah satunya adalah dengan Preference Ranking Organization Method for Enrichment Evaluation (PROMETHEE) [11].

Metode MCDM - PROMETHEE telah digunakan untuk melakukan audit energi dan penentuan konservasi energi yang akan dilakukan untuk meningkatkan efisiensi penggunaan listrik di Rumah Sakit Haji Surabaya [12]. Metode MCDM - PROMETHEE yang dikombinasikan dengan analytical network process (ANP) juga telah digunakan untuk melakukan pemilihan alternatif penghematan listrik di perusahaan [13]. Artikel ini akan membahas penggunaan sumber daya energi dalam proses produksi batik cap yang ada di Kampung Batik Laweyan dan merumuskan alternatif usaha peningkatan efisiensi penggunaan sumber energi tersebut dengan metode MCDM - PROMETHEE.

\section{METODOLOGI PENELITIAN}

Pada proses pembuatan batik cap, alat yang digunakan yaitu cap (semacam stempel besar yang terbuat dari tembaga) yang sudah didesain dengan motif tertentu dengan ukuran $20 \mathrm{~cm} \times 20 \mathrm{~cm}$. Proses pembuatan batik cap dilakukan dengan urutan proses berikut: (1) Kain mori diletakkan di atas meja dengan alas dibawahnya menggunakan bahan yang empuk,(2) Lilin (wax) direbus hingga suhu $60-70{ }^{\circ} \mathrm{C}$, (3) Cap dicelupkan ke lilin yang telah mencair dengan kedalaman $2 \mathrm{~cm}$ saja dari bagian bawah cap,(4) Kemudian kain mori dicap dengan tekanan yang cukup supaya rapih. Pada proses ini, cairan malam akan meresap ke dalam porikain mori dan membentuk motif tertentu, (5) Proses pewarnaan dengan mencelupkan kain mori yang sudah dicap ke dalam tangki yang berisi cairan pewarna,(6) Kain mori direbus supaya cairan malam yang menempel hilang dari kain, atau dikenal sebagai proses pelorodan,(7) Proses pengecapan, pewarnaan, dan pelorodan diulangi kembali, jika ingin diberikan kombinasi beberapa warna,(8) Proses pembersihan dan pencerahan warna dengan menggunakan soda,(9) Pengeringan kain dengan cara dijemur [14].

Pengamatan dilakukan pada proses produksi yang memerlukan sumber daya energi, dengan mencatat hasil produksi pada proses tersebut dan kuantitas sumber daya. Berdasarkan pengamatan awal, proses produksi yang memerlukan sumber daya energi meliputi proses pengecapan, proses pewarnaan, proses pencucian, dan proses pelorodan. Perhitungan efisiensi dilakukan berdasarkan jumlah hasil produksi dibagi dengan kuantitas sumber daya yang digunakan. Untuk menyamakan satuan energi yang berbeda dari beberapa jenis energi yang digunakan digunakan referensi [15].

Penentuan alternatif penghematan sumber daya energi pada proses produksi batik cap dilakukan dengan melakukan wawancara dengan stakeholder yang terkait dalam proses tersebut. Alternatif yang diusulkan memperhatikan sistem pengelolaan energi yang berkelanjutan [16]. Pemilihan alternatif dilakukan dengan menggunakan metode 
PROMETHEE, dimana penilaian preferensi bobot kriteria dilakukan oleh pemilik usaha yang dianggap memiliki kapabilitas yang memadai.

\section{HASIL DAN PEMBAHASAN}

Artikel ini disusun berdasarkan pengamatan yang dilakukan pada proses pembuatan batik cap di UKM Batik Supriyarso, yang terletak di dalam wilayah Kampoeng Batik Laweyan, Kota Surakarta. Pengamatan dilakukan pada bulan Juni 2017.

Konsumsi energi pada proses pembuatan batik cap terjadi pada beberapa tahapan proses. Konsumen energi pada tiap tahap proses, dapat dilihat pada Tabel 1. Dari Tabel 1 dapat dilihat bahwa penggunaan energi untuk proses pembuatan batik cap dapat dikelompokkan dalam bentuk energi listrik, energi air, energi elpiji atau gas, dan energi kayu bakar.

Tabel 1. Jenis energi pada proses pembuatan batik cap

\begin{tabular}{ccl}
\hline No. & \multicolumn{1}{c}{ Tahap proses } & \multicolumn{1}{c}{ Ragam penggunaan energi } \\
\hline 1. & Proses pengecapan & 1. Penggunaan listrik untuk lampu penerangan ruangan. \\
& & 2. Penggunaan gas LPG untuk mencairkan lilin (wax). \\
2. Proses pewarnaan & $\begin{array}{l}\text { 1. Penggunaan air untuk melarutkan biang warna. } \\
\text { 3. Proses pencucian }\end{array}$ & $\begin{array}{l}\text { 2. Penggunaan listrik untuk menjalankan mesin pewarna. } \\
\text { 1. Penggunaan air untuk melarutkan kotoran. }\end{array}$ \\
& $\begin{array}{l}\text { 2. Penggunaan energi listrik untuk mengalirkan air pada bak } \\
\text { pencucian. }\end{array}$ \\
4. Proses pelorodan & $\begin{array}{l}\text { 1. Penggunaan air untuk me-lorod-kan lilin (wax). } \\
\text { 2. Penggunaan energi listrik untuk mengalirkan air ke bak }\end{array}$ \\
& & $\begin{array}{l}\text { 3. Pelorodan. } \\
\text { pelogunaan kayu bakar pada pemanasan air untuk }\end{array}$ \\
\hline
\end{tabular}

Perhitungan konsumsi energi untuk proses pembuatan batik cap dilakukan untuk masing-masing jenis sumber daya energi yang digunakan. Penggunaan energi listrik ditunjukkan pada Tabel 2 sampai dengan Tabel 5. Tabel 2 menunjukkan penggunaan pada proses pengecapan, yaitu untuk penerangan ruangan, dengan konsumsi sebesar 6,889 Wh per potong. Tabel 3 menunjukkan konsumsi untuk menjalankan mesin pewarna, dengan tingkat konsumsi sebesar $0,368 \mathrm{Wh}$ per potong. Tabel 4 menunjukkan energi untuk pengisian air pada bak pencucian, dimana konsumsi energi listrik rata-ratanya adalah 3,956 Wh per potong. Tabel 5 menunjukkan energi untuk pengisian air pada bak pelorodan dengan konsumsi sebesar 0,029 Wh per potong.

Tabel 2. Penggunaan energi listrik untuk proses pengecapan

\begin{tabular}{cccccc}
\hline Hari & $\begin{array}{c}\text { Daya } \\
\text { lampu } \\
\text { (Watt) }\end{array}$ & $\begin{array}{c}\text { Pemakaian } \\
\text { (jam) }\end{array}$ & $\begin{array}{c}\text { Total } \\
\text { energi } \\
(\text { Wh) }\end{array}$ & $\begin{array}{c}\text { Jumlah } \\
\text { Produk } \\
(\mathrm{ptg})\end{array}$ & $\begin{array}{c}\text { Konsumsi } \\
\text { energi } \\
(\mathrm{Wh} / \mathrm{ptg})\end{array}$ \\
\hline 2 Juni & 135 & 7 & 945 & 125 & 7,56 \\
3 Juni & 120 & 7 & 840 & 125 & 6,72 \\
5 Juni & 135 & 7 & 945 & 140 & 6,75 \\
6 Juni & 135 & 7 & 945 & 150 & 6,30 \\
7 Juni & 96 & 7 & 672 & 150 & 4,48 \\
9 Juni & 120 & 7 & 840 & 105 & 8,00 \\
10 Juni & 135 & 7 & 945 & 90 & 10,50 \\
12 Juni & 120 & 7 & 840 & 100 & 8,40 \\
13 Juni & 105 & 7 & 735 & 130 & 5,65 \\
14 Juni & 135 & 7 & 945 & 125 & 7,56 \\
15 Juni & 120 & 7 & 840 & 145 & 5,79 \\
16 Juni & 135 & 7 & 945 & 125 & 7,56 \\
\hline Rata-rata & 123,84 & 7 & 866,86 & 125,833 & 6,889 \\
\hline
\end{tabular}


Tabel 3. Penggunaan energi listrik untuk mesin pewarna

\begin{tabular}{cccccc}
\hline Hari & $\begin{array}{c}\text { Daya } \\
\text { mesin } \\
\text { (Watt) }\end{array}$ & $\begin{array}{c}\text { Pemakaian } \\
\text { (jam) }\end{array}$ & $\begin{array}{c}\text { Total } \\
\text { energi } \\
(\text { Wh })\end{array}$ & $\begin{array}{c}\text { Jumlah } \\
\text { Produk } \\
(\text { ptg })\end{array}$ & $\begin{array}{c}\text { Konsumsi } \\
\text { energi } \\
(\text { Wh/ptg) }\end{array}$ \\
\hline 2 Juni & 100 & 0,467 & 46,667 & 125 & 0,373 \\
3 Juni & 100 & 0,583 & 58,333 & 125 & 0,467 \\
5 Juni & 100 & 0,583 & 58,333 & 140 & 0,417 \\
6 Juni & 100 & 0,500 & 50,000 & 150 & 0,333 \\
7 Juni & 100 & 0,333 & 33,333 & 150 & 0,222 \\
9 Juni & 100 & 0,367 & 36,667 & 105 & 0,349 \\
10 Juni & 100 & 0,333 & 33,333 & 90 & 0,370 \\
12 Juni & 100 & 0,467 & 46,667 & 100 & 0,467 \\
13 Juni & 100 & 0,433 & 43,333 & 130 & 0,333 \\
14 Juni & 100 & 0,458 & 45,833 & 125 & 0,367 \\
15 Juni & 100 & 0,442 & 44,147 & 145 & 0,305 \\
16 Juni & 100 & 0,517 & 51,667 & 125 & 0,413 \\
\hline Rata-rata & 100 & 0,457 & 45,667 & 125,833 & 0,368 \\
\hline
\end{tabular}

Tabel 4. Penggunaan energi listrik untuk pengisian air bak pencucian

\begin{tabular}{cccccc}
\hline Hari & $\begin{array}{c}\text { Daya } \\
\text { mesin } \\
\text { (Watt) }\end{array}$ & $\begin{array}{c}\text { Pemakaian } \\
\text { (jam) }\end{array}$ & $\begin{array}{c}\text { Total } \\
\text { energi } \\
(\mathrm{Wh})\end{array}$ & $\begin{array}{c}\text { Jumlah } \\
\text { Produk } \\
(\mathrm{ptg})\end{array}$ & $\begin{array}{c}\text { Konsumsi } \\
\text { energi } \\
(\mathrm{Wh} / \mathrm{ptg})\end{array}$ \\
\hline 2 Juni & 200 & 2,489 & 497,778 & 125 & 3,982 \\
3 Juni & 200 & 2,489 & 497,778 & 125 & 3,982 \\
5 Juni & 200 & 2,489 & 497,778 & 140 & 3,556 \\
6 Juni & 200 & 2,489 & 497,778 & 150 & 3,318 \\
7 Juni & 200 & 2,489 & 497,778 & 150 & 3,318 \\
9 Juni & 200 & 2,489 & 497,778 & 105 & 4,741 \\
10 Juni & 200 & 2,489 & 497,778 & 90 & 5,531 \\
12 Juni & 200 & 2,489 & 497,778 & 100 & 4,978 \\
13 Juni & 200 & 2,489 & 497,778 & 130 & 3,829 \\
14 Juni & 200 & 2,489 & 497,778 & 125 & 3,982 \\
15 Juni & 200 & 2,489 & 497,778 & 145 & 3,433 \\
16 Juni & 200 & 2,489 & 497,778 & 125 & 3,982 \\
\hline Rata-rata & 200 & 2,489 & 497,778 & 125,833 & 3,956 \\
\hline
\end{tabular}

Tabel 5. Penggunaan energi listrik untuk pengisian air bak pelorodan

\begin{tabular}{cccccc}
\hline Hari & $\begin{array}{c}\text { Daya } \\
\text { mesin } \\
\text { (Watt) }\end{array}$ & $\begin{array}{c}\text { Pemakaian } \\
\text { (jam) }\end{array}$ & $\begin{array}{c}\text { Total } \\
\text { energi } \\
(\text { Wh })\end{array}$ & $\begin{array}{c}\text { Jumlah } \\
\text { Produk } \\
(\text { ptg })\end{array}$ & $\begin{array}{c}\text { Konsumsi } \\
\text { energi } \\
(\text { Wh/ptg) }\end{array}$ \\
\hline 2 Juni & 200 & 0,049 & 9,878 & 300 & 0,033 \\
4 Juni & 200 & 0,043 & 8,642 & 390 & 0,022 \\
7 Juni & 200 & 0,051 & 10,123 & 325 & 0,031 \\
11 Juni & 200 & 0,052 & 10,494 & 325 & 0,032 \\
15 Juni & 200 & 0,059 & 11,728 & 425 & 0,028 \\
\hline Rata-rata & 200 & 0,051 & 10,173 & 353 & 0,029 \\
\hline
\end{tabular}

Dari data yang ditunjukkan pada Tabel 2 sampai dengan Tabel 5, diketahui bahwa total konsumsi energi listrik untuk proses pembuatan batik cap secara keseluruhan adalah sebesar 11,242 Wh untuk tiap potong batik cap. Konsumsi terbesar penggunaan listrik terjadi pada proses pengecapan, yaitu untuk lampu penerangan ruangan, yaitu sebesar 6,889.

Penggunaan sumber daya air diperlihatkan pada Tabel 6 dan Tabel 7. Pada proses pewarnaan, penggunaan air hanya untuk melarutkan zat pewarna dengan volume yang tidak besar, sehingga diabaikan dalam perhitungan. Tabel 6 menunjukkan penggunaan air pada proses pencucian rata-rata sebanyak 32,042 liter per potong. Tabel 7 menunjukkan penggunaan air pada proses pelorodan sebesar 0,237 liter per potong. 
Tabel 6. Penggunaan air untuk proses pencucian

\begin{tabular}{cccc}
\hline Hari & $\begin{array}{c}\text { Volume air } \\
(\text { liter })\end{array}$ & $\begin{array}{c}\text { Jumlah Produk } \\
(\text { ptg })\end{array}$ & $\begin{array}{c}\text { Konsumsi air } \\
\text { (liter/ptg) }\end{array}$ \\
\hline 2 Juni & 4.032 & 125 & 32,256 \\
3 Juni & 4.032 & 125 & 32,256 \\
5 Juni & 4.032 & 140 & 28,800 \\
6 Juni & 4.032 & 150 & 26,880 \\
7 Juni & 4.032 & 150 & 26,880 \\
9 Juni & 4.032 & 105 & 38,400 \\
10 Juni & 4.032 & 90 & 44,800 \\
12 Juni & 4.032 & 100 & 40,320 \\
13 Juni & 4.032 & 130 & 31,015 \\
14 Juni & 4.032 & 125 & 32,256 \\
15 Juni & 4.032 & 145 & 27,807 \\
16 Juni & 4.032 & 125 & 32,256 \\
\hline Rata-rata & 4.032 & 125,833 & 32,042 \\
\hline
\end{tabular}

Tabel 7. Penggunaan air untuk proses pelorodan

\begin{tabular}{cccc}
\hline Hari & $\begin{array}{c}\text { Volume air } \\
\text { (liter) }\end{array}$ & $\begin{array}{c}\text { Jumlah Produk } \\
(\mathrm{ptg})\end{array}$ & $\begin{array}{c}\text { Konsumsi air } \\
\text { (liter/ptg) }\end{array}$ \\
\hline 2 Juni & 80 & 300 & 0,267 \\
4 Juni & 70 & 390 & 0,179 \\
7 Juni & 82 & 325 & 0,252 \\
11 Juni & 85 & 325 & 0,262 \\
15 Juni & 95 & 425 & 0,224 \\
\hline Rata-rata & & & 0,237 \\
\hline
\end{tabular}

Dari data yang ditunjukkan pada Tabel 6 dan Tabel 7, dapat diketahui bahwa konsumsi air untuk pembuatan batik cap adalah sebesar 32,279 liter per potong. Konsumsi air secara dominan dilakukan pada proses pencucian, yaitu sebesar 32,042 liter per potong.

Tabel 8. Penggunaan energi gas elpiji pada proses pengecapan

\begin{tabular}{cccc}
\hline Hari & $\begin{array}{c}\text { Berat gas } \\
\text { LPG }(\mathrm{kg})\end{array}$ & $\begin{array}{c}\text { Jumlah } \\
\text { Produk }(\mathrm{ptg})\end{array}$ & $\begin{array}{c}\text { Konsumsi gas } \\
\text { LPG }(\mathrm{kg} / \mathrm{ptg})\end{array}$ \\
\hline 2 Juni & 6 & 125 & 0,048 \\
3 Juni & 9 & 125 & 0,072 \\
5 Juni & 9 & 140 & 0,064 \\
6 Juni & 6 & 150 & 0,040 \\
7 Juni & 12 & 150 & 0,080 \\
9 Juni & 6 & 105 & 0,057 \\
10 Juni & 12 & 90 & 0,133 \\
12 Juni & 6 & 100 & 0,060 \\
13 Juni & 6 & 130 & 0,046 \\
14 Juni & 12 & 125 & 0,095 \\
15 Juni & 9 & 145 & 0,062 \\
16 Juni & 6 & 125 & 0,048 \\
\hline Rata-rata & 8,25 & 125,833 & 0,066 \\
\hline
\end{tabular}

Tabel 9. Penggunaan kayu bakar untuk proses pelorodan

\begin{tabular}{cccc}
\hline Hari & $\begin{array}{c}\text { Kuantitas kayu } \\
\text { bakar }(\mathrm{kg})\end{array}$ & $\begin{array}{c}\text { Jumlah Produk } \\
(\mathrm{ptg})\end{array}$ & $\begin{array}{c}\text { Konsumsi kayu } \\
\text { bakar (liter/ptg) }\end{array}$ \\
\hline 2 Juni & 92 & 300 & 0,307 \\
4 Juni & 110 & 390 & 0,282 \\
7 Juni & 102 & 325 & 0,314 \\
11 Juni & 102 & 325 & 0,314 \\
15 Juni & 119 & 425 & 0,280 \\
\hline Rata-rata & & & 0,297 \\
\hline
\end{tabular}


Tabel 8 menunjukkan tingkat konsumsi gas elpiji pada proses pengecapan sebesar 0,066 $\mathrm{kg}$ per potong. Dengan tingkat energi sebesar $49.235,9 \mathrm{~kJ} / \mathrm{kg}$, maka tingkat konsumsi gas elpiji pada proses pengecapan sebesar 3.249,57 kJ atau setara 903,38 Wh per potong.Tabel 9 menunjukkan konsumsi kayu bakar pada proses pelorodan sebesar 0,297 kg per potong. Dengan tingkat kalor sebesar $4.500 \mathrm{Wh} / \mathrm{kg}$, maka diperoleh tingkat konsumsi kayu bakar pada proses pelorodan sebesar 1.336,5 Wh per potong produk batik cap.

Berdasarkan perhitungan tingkat konsumsi energi untuk tahapan proses dan berdasar jenis energi yang digunakan, disusun alternatif penghematan energi pada perusahaan. Penyusunan alternatif dilakukan dengan mempertimbangkan 5 kriteria, yaitu: (1) dukungan infrastruktur, (2) analisis kelayakan ekonomi, (3) dukungan teknologi, (4) budaya kerja para karyawan, dan (5) pelatihan yang perlu dilakukan. Gambar 1 menunjukkan pohon keputusan untuk penentuan alternatif penghematan energi yang akan dilakukan di UKM,

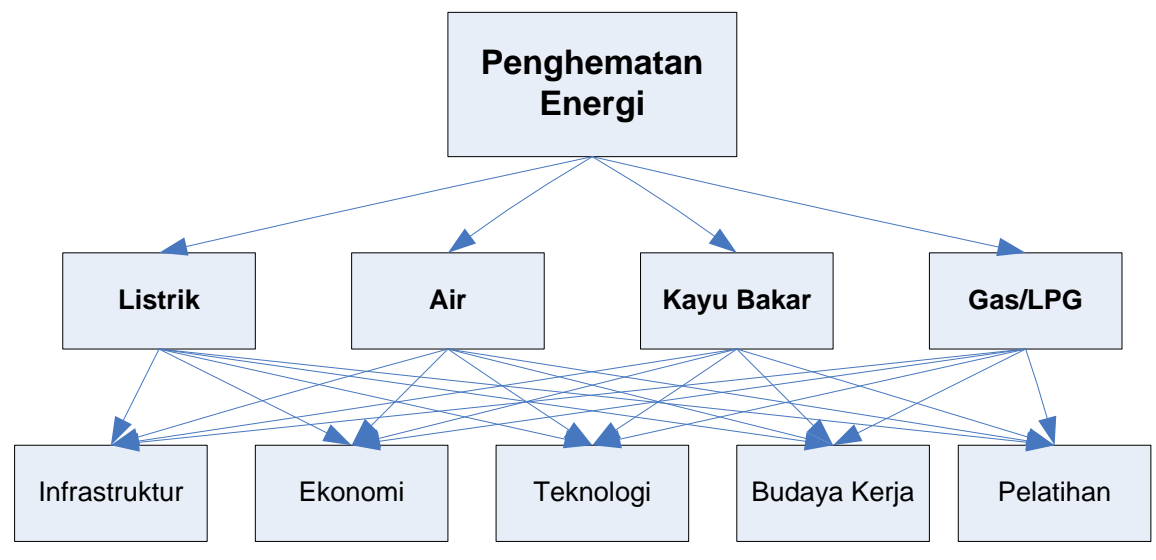

Gambar 1. Pohon keputusan untuk penghematan energi

Alternatif penghematan penggunaan energi listrik, meliputi: (L1) pembuatan prosedur operasional baku untuk penggunaan listrik, (L2) melakukan pekerjaan sipil minor, (L3) pengantian dengan lampu hemat energi dan (L4) pemasangan tanda-tanda penggunaan listrik.Alternatif penghematan penggunaan air, meliputi: (A1) pembuatan prosedur operasional baku untuk penggunaan air, (A2) mengubah perilaku pekerja, (A3) pemasangon tandon air, dan (A4) pemasangan tanda-tanda penggunaan air.Alternatif penghematan penggunaan kayu bakar, meliputi: (K1) modifikasi penutup tungku, (K2) mengubah perilaku pekerja, (K3) penambahan SDM, dan (K4) pelatihan SDM.Alternatif penghematan penggunaan gas elpiji, meliputi (G1) pembuatan prosedur operasional baku untuk penggunaan gas elpiji, (G2) mengubah perilaku pekerja, (G3) modifikasi penutup kompor, dan (G4) pelatihan SDM.

Tabel 10. Rekapitulasi bobot kriteria penghematan energi listrik

\begin{tabular}{lcccc}
\hline Alternatif & $\begin{array}{c}\text { Pembuatan } \\
\text { prosedur } \\
\text { operasional } \\
\text { Kaku (L1) }\end{array}$ & $\begin{array}{c}\text { Melakukan } \\
\text { pekerjaan } \\
\text { sipil minor } \\
\text { (L2) }\end{array}$ & $\begin{array}{c}\text { Pengantian } \\
\text { dengan lampu } \\
\text { hemat energi } \\
\text { (L3) }\end{array}$ & $\begin{array}{c}\text { Pemasangan } \\
\text { tanda-tanda } \\
\text { penggunaan } \\
\text { listrik (L4) }\end{array}$ \\
\hline Infrastruktur & 2.5 & 4 & 2.5 & 4 \\
Ekonomi & 4 & 1 & 2.5 & 4 \\
Teknologi & 2.5 & 2.5 & 4 & 2.5 \\
Budaya kerja & 4 & 4 & 2.5 & 2.5 \\
Pelatihan & 4 & 2.5 & 1 & 4 \\
\hline
\end{tabular}


Tabel 10 menunjukkan hasil penilaian bobot preferensi penilaian pada kriteria terkait upaya penghematan energi listrik. Berdasarkan perhitungan dengan metode PROMETHEE, nilai leaving flow, entering flow, dan net flow, dapat dilihat pada Tabel 11.Nilai tertinggi dengan nilai 0,03333 dapat dilakukan dengan pembuatan prosedur operasional baku (L1) dan pembuatan tanda-tanda untuk penggunaan listrik (L4). Kedua alternatif tersebut diharapkan dapat meningkatkan efisiensi, dengan tingkat yang sama. Pembuatan prosedur operasionalbakudapat memberikan aturan kerja yang harus dilakukan, sedangkan pembuatan tanda-tanda pada sumber energi dapat mengatur penggunaan energi sesuai kebutuhan.

Tabel 11. Perhitungan leaving flow,entering flow, dan net flowuntuk penghematan energi listrik

\begin{tabular}{|c|c|c|c|c|c|c|}
\hline Alternatif & L1 & L2 & L3 & L4 & $\begin{array}{c}\text { Leaving } \\
\text { Flow }\end{array}$ & Net flow \\
\hline L1 & - & 0.1 & 0.1 & 0.04 & 0.0667 & 0.0333 \\
\hline L2 & 0.0 & - & 0.1 & 0.0 & 0.06 & 0.0067 \\
\hline L3 & 0.0 & 0.0 & - & 0.0 & 0.0333 & -0.0733 \\
\hline L4 & 0.0 & 0.1 & 0.1 & - & 0.0733 & 0.0333 \\
\hline Entering Flo & 0.0333 & 0.0533 & 0.1067 & 0.04 & & \\
\hline
\end{tabular}

Tabel 12. Rekapitulasi bobot kriteria penghematan energi air

\begin{tabular}{lcccc}
\hline \multicolumn{1}{c}{ Alternatif } & $\begin{array}{c}\text { Pembuatan } \\
\text { prosedur } \\
\text { operasional } \\
\text { baku (A1) }\end{array}$ & $\begin{array}{c}\text { Mengubah } \\
\text { perilaku } \\
\text { pekerja } \\
\text { (A2) }\end{array}$ & $\begin{array}{c}\text { Pemasangan } \\
\text { tendon air } \\
\text { (A3) }\end{array}$ & $\begin{array}{c}\text { Pemasangan } \\
\text { tanda-tanda } \\
\text { penggunaan } \\
\text { air (A4) }\end{array}$ \\
\hline Infrastruktur & 1 & 1 & 4 & 4 \\
Ekonomi & 4 & 4 & 2.5 & 4 \\
Teknologi & 2.5 & 2.5 & 4 & 2.5 \\
Budaya kerja & 2.5 & 4 & 2 & 4 \\
Pelatihan & 2.5 & 4 & 1 & 4 \\
\hline
\end{tabular}

Tabel 13. Perhitungan leaving flow, entering flow, dan net flow untuk penghematan energi air

\begin{tabular}{|c|c|c|c|c|c|c|}
\hline Alternatif & A1 & A2 & A3 & A4 & $\begin{array}{l}\text { Leaving } \\
\text { Flow }\end{array}$ & Net flow \\
\hline A1 & - & 0.0 & 0.06 & 0.0 & 0.02 & -0.0467 \\
\hline A2 & 0.04 & - & 0.1 & 0.0 & 0.0467 & 0.0067 \\
\hline A3 & 0.1 & 0.1 & - & 0.0 & 0.0667 & -0.02 \\
\hline A4 & 0.1 & 0.0 & 0.1 & - & 0.0733 & 0.06 \\
\hline
\end{tabular}

Tabel 12 menunjukkan hasil penilaian bobot preferensi penilaian pada kriteria terkait upaya penghematan energi sumber daya air. Berdasarkan perhitungan dengan metode PROMETHEE, hasilnya dapat dilihat pada Tabel 13.Nilai tertinggi untuk penghematan energi pada sumber air (dengan nilai 0,06 ) dapat dilakukan dengan pembuatan tanda-tanda untuk penggunaan sumber daya air (A4). Pembuatan tanda-tanda pada sumber energi air dimaksudkan agar para pekerja dapat memanfaatkan energi sesuai kebutuhan. 
$\underline{\text { Tabel 14. Rekapitulasi bobot kriteria penghematan sumber energi kayu bakar }}$

\begin{tabular}{lcccc}
\hline Alternatif & $\begin{array}{c}\text { Modifikasi } \\
\text { penutup } \\
\text { tungku } \\
\text { Kriteria }\end{array}$ & $\begin{array}{c}\text { Mengubah } \\
\text { perilaku } \\
\text { pekerja } \\
(\mathrm{K} 2)\end{array}$ & $\begin{array}{c}\text { Penambahan } \\
\text { sumber daya } \\
\text { manusia } \\
(\mathrm{K} 3)\end{array}$ & $\begin{array}{c}\text { Pelatihan } \\
\text { sumber daya } \\
\text { manusia } \\
(\mathrm{K} 4)\end{array}$ \\
\hline Infrastruktur & 4 & 1 & 1 & 1 \\
Ekonomi & 4 & 4 & 1 & 2.5 \\
Teknologi & 2.5 & 1 & 1 & 2.5 \\
Budaya kerja & 2.5 & 4 & 2.5 & 4 \\
Pelatihan & 2.5 & 4 & 2.5 & 4 \\
\hline
\end{tabular}

Tabel 15. Perhitungan leaving flow,entering flow, dan net flow untukpenghematan energi kayu bakar

\begin{tabular}{|c|c|c|c|c|c|c|}
\hline Alternatif & K1 & $\mathrm{K} 2$ & $\mathrm{~K} 3$ & $\mathrm{~K} 4$ & $\begin{array}{c}\text { Leaving } \\
\text { Flow }\end{array}$ & Net flow \\
\hline K1 & - & 0.1 & 0.1 & 0.06 & 0.0733 & 0.0467 \\
\hline K2 & 0.04 & - & 0.1 & 0.0 & 0.0467 & 0.0200 \\
\hline K3 & 0.0 & 0.0 & - & 0.0 & 0 & -0.0867 \\
\hline K4 & 0.0 & 0.0 & 0.1 & - & 0.0467 & 0.0200 \\
\hline Entering Flow & 0.0267 & 0.0267 & 0.0867 & 0.0267 & & \\
\hline
\end{tabular}

Tabel 16. Rekapitulasi bobot kriteria penghematan energi gas LPG

\begin{tabular}{lcccc}
\hline Alternatif & $\begin{array}{c}\text { Pembuatan } \\
\text { prosedur } \\
\text { operasional } \\
\text { baku (G1) }\end{array}$ & $\begin{array}{c}\text { Mengubah } \\
\text { perilaku } \\
\text { pekerja } \\
(\mathrm{G} 2)\end{array}$ & $\begin{array}{c}\text { Modifikasi } \\
\text { penutup } \\
\text { kompor } \\
(\mathrm{G} 3)\end{array}$ & $\begin{array}{c}\text { Pelatihan } \\
\text { sumber daya } \\
\text { manusia (G4) }\end{array}$ \\
\hline Infrastruktur & 1 & 2.5 & 4 & 1 \\
Ekonomi & 4 & 4 & 2.5 & 4 \\
Teknologi & 2.5 & 1 & 2.5 & 1 \\
Budaya kerja & 2.5 & 4 & 2.5 & 2.5 \\
Pelatihan & 2.5 & 2.5 & 1 & 4 \\
\hline
\end{tabular}

Tabel 17. Perhitungan leaving flow, entering flow, dan net flowuntuk penghematan energi gas

\begin{tabular}{cccccccc}
\hline Alternatif & G1 & G2 & G3 & G4 & $\begin{array}{c}\text { Leaving } \\
\text { Flow }\end{array}$ & & Net flow \\
\cline { 1 - 1 } G1 & & 0.04 & 0.06 & 0.04 & 0.0467 & & 0.0067 \\
G2 & 0.06 & & 0.1 & 0.1 & 0.07333 & & 0.0333 \\
G3 & 0.0 & 0.1 & & 0.1 & 0.06 & & -0.0200 \\
G4 & 0.0 & 0.0 & 0.1 & & 0.04 & & -0.0200 \\
\hline Entering Flow & 0.04 & 0.04 & 0.08 & 0.06 & & &
\end{tabular}

Tabel 14 menunjukkan hasil penilaian bobot preferensi terkait upaya penghematan penggunaan kayu bakar. Berdasarkan perhitungan dengan metodePROMETHEE, hasilnya dapat dilihat pada Tabel 15.Nilai tertinggi untuk penghematan penggunaan kayu bakar (dengan nilai 0,0467 ) melakukan modifikasi pada penutup tungku (K1). Modifikasi penutup tungku diharapkan dapat mengurangi panas yang terbuang ke lingkungan.

Tabel 16 menunjukkan hasil penilaian bobot preferensi pada kriteria terkait upaya penghematan pemakaian gas elpiji. Berdasarkan perhitungan dengan metodePROMETHEE, hasilnya dapat dilihat pada Tabel 17.Nilai tertinggi untuk penghematan energi pada penggunaan gas elpiji (dengan nilai 0,0333) dapat dilakukan dengan mengubah perilaku 
pekerja (G2). Perubahan perilaku pekerja dalam menggunakan gas elpiji dapat memberikan dampak kepada para pekerja untuk lebih mengetahui aturan kerja yang harus dilakukan.

\section{KESIMPULAN}

Jenis energi yang digunakan pada proses pembuatan batik cap memiliki perbedaan untuk tiap tahapan proses produksinya. Tingkat konsumsi untuk tiap jenis energi pada setiap proses juga berbeda. Proses pengecapan mengkonsumsi energi listrik dan gas elpiji. Proses pencucian lebih dominan penggunaan air. Proses pelorodan lebih dominan penggunaan kayu bakar. Sedangkan proses pewarnaan relatif rendah tingkat konsumsi energinya. Dengan menggunakan metode MCDM - PROMETHEE, artikel ini memberikan usulan penghematan energi untuk masing-masing jenis energi.Untuk penghematan listrik, diusulkan pembuatan prosedur operasional penggunaan listrik dan memberikan tanda-tanda penggunaan listrik.Untuk penghematan air dilakukan dengan pembuatan tanda-tanda penggunaan air. Untuk penghematan gas elpiji dan kayu bakar disarankan dengan melakukan modifikasi pada penutup tungku.

\section{DAFTAR PUSTAKA}

[1] Musman, A.; Arini, A.B. (2011). Batik Warisan Adiluhung Nusantara. Yogyakarta: G-Media.

[2] Wulandari, A. (2011). Batik Nusantara: Makna Filosofis, Cara Pembuatan,dan Industri Batik. Yogyakarta: CV. Andi Offset.

[3] Nurainun; Heriyana; Rasyimah. (2008).“Analisis industri batik di Indonesia”. Fokus Ekonomi, Vol.7 (3), hal.: $124-135$.

[4] Pratomo, A.S.; Antariksa, A.; Hariyani, S. (2006)."Pelestarian kawasan kampung batik Laweyan Kota Surakarta". Dimensi Teknik Arsitektur, Vol. 34 (2), hal.: 93 105.

[5] Astra, I M. (2010).“Energi dan dampaknya terhadap lingkungan”. Jurnal Meteorologi dan Geofisika, Vol. 11 (2),hal.:127-135.

[6] So, P.Y. 2014."Implementasikebijakankonservasienergi di Indonesia".E-Journal Graduate Unpar, Vol. 1 (1), hal.: 1 - 13.

[7] Febrian, D.R. (2015). Analisis Peluang Penghematan Konsumsi Energi pada Sistem Peralatan Listrik di Fakultas Pertanian Lampung Menggunakan Program Microsoft Visual Basic 6.0. Skripsi (tidak diterbitkan). JurusanTeknik Elektro, FakultasTeknik, Universitas Lampung.

[8] Sugiyono, A.; Anindhita, A.; Wahid, L.M.A.; Adiarso, A. (2016). Outlook Energi Indonesia (Pengembangan Energiuntuk Mendukung Industri Hijau).Jakarta: Badan Pengkajian dan Penerapan Teknologi (BPPT).

[9] Atmosoeprapto, K. (2000). Produktivitas Aktualisasi Budaya Perusahaan. Jakarta: PT. Elex Media Komputindo.

[10] Ishizaka, A.; Nemery, P. (2013).Multi-Criteria Decision Analysis. United Kingdom: John Wiley\&Sons,.Ltd.

[11] Brans, J.P.; Vincke, P.H.; Mareschal, B. (1986). "How to Select and How to Rank Project: The PROMETHEE Method". Europan Journal of Operational Research, Vol. 24, pp.: $228-238$.

[12] Adiprama, T.R.; Ciptomulyono, U.S. (2012).“Audit energi dengan pendekatan metode MCDM-PROMETHEEuntuk konservasi serta efisiensi listrik di Rumah Sakit Haji Surabaya". Jurnal Teknik POMITS, Vol. 1 (1), hal.: 1 - 6.

[13] Putri, A.D.; Sugiono, S.; Sari, R.A. (2015)."Pemilihan alternatif peluang hemat energi listrik dengan pendekatan metode ANP dan PROMETHEE".Jurnal Rekayasa dan Manajemen Sistem Industri, Vol. 3 (1), hal.142-153.

[14] Nurdalia, I. (2006). Kajian dan Analisis Peluang Penerapan Produksi Bersih Pada Usaha Kecil Batik Cap. Thesis (tidak diterbitkan). Program Magister Ilmu Lingkungan Program Pascasarjana Universitas Diponegoro Semarang. 
[15] Thumann, A.; Younger, W.J. (2008).Handbook of Energy Audits. UK: Taylor \& Francis Ltd.

[16] Tester, J.W.; Drake, E.M.; Driscoll, M.J.; Golay, M.W.; Peters, W.A. (2012). Sustainable Energy: Choosing Among Options. 2nd edition. USA: MIT Press. 